\title{
Simulation of Dynamic Response of Small Wind-Photovoltaic-Fuel Cell Hybrid Energy System
}

\author{
Saeid Esmaeilii, ${ }^{1,2}$, Mehdi Shafiee ${ }^{1,3}$ \\ ${ }^{1}$ Energy Department, International Center for Science, High Technology \& Environmental Sciences, Kerman, Iran; ${ }^{2}$ Electrical De- \\ partment, Shahid Bahonar University of Kerman, Kerman, Iran; ${ }^{3}$ Electrical Department, Ferdowsi University of Mashhad, Mashhad, \\ Iran. \\ Email: sesm76@yahoo.com,shafiemehdi@yahoo.com
}

Received October $26^{\text {th }}, 2011$; revised May $16^{\text {th }}, 2012$; accepted May $23^{\text {rd }}, 2012$

\begin{abstract}
Renewable energy systems are of importance as being modular, nature-friendly and domestic. Among renewable energy systems, a great deal of research has been conducted especially on photovoltaic effect, wind energy and fuel cell in the recent years. This paper describes dynamic modeling and simulation results of a small wind-photovoltaic-fuel cell hybrid energy system. The hybrid system consists of a $500 \mathrm{~W}$ wind turbine, a photovoltaic, a proton exchange membrane fuel cell (PEMFC), ultracapacitors, an electrolyzer, a boost converter, controllers and a power converter that simulated using MATLAB solver. This kind of hybrid system is completely stand-alone, reliable and has high efficiency. In order to minimize sudden variations in voltage magnitude ultracapacitors are proposed. Power converter and inverter are used to produce ac output power. Dynamics of fuel-cell component such as double layer capacitance are also taken into account. Control scheme of fuel-cell flow controller and voltage regulators are based on PID controllers. Dynamic responses of the system for a step change in the electrical load and wind speed are presented. Results showed that the ability of the system in adapting itself to sudden changes and new conditions. Combination of PV and wind renewable sources is made the advantage of using this system in regions which have higher wind speeds in the seasons that suffers from less sunny days and vice versa.
\end{abstract}

Keywords: Wind Energy; Photovoltaic; Fuel-Cell; Hybrid Energy Systems; Dynamics of Energy System

\section{Introduction}

The rapid depletion of fossil fuel resources on a worldwide basis has necessitated an urgent search for alternative energy sources to meet to the present day demands. Alternative energy resources, such as solar and wind energies, are clean, inexhaustible and environment friendly potential resources of renewable energy options. It is prudent that neither a standalone solar nor a wind energy system can provide a continuous supply of energy due to seasonal and periodical variations [1-3]. To solve these drawbacks conventional battery storage has been used. But batteries can store a limited amount of power for a short period of time. For long-term storage electrical power produced by wind turbines or PV arrays can be converted into hydrogen using an electrolyzer for later use in fuel cell. So these conventional batteries can be replaced with fuel cells as non-polluting and high efficiency storage devices. Advantages in wind and PV energy technologies are the main reason of using hybrid Wind/PV configurations, and fuel-cells can be work in parallel with Wind/PV system as the device which can save and generate electrical energy where it is necessary. In addition the excess heat from a fuel-cell can also be used for space heating or for the residential hot water. This kind of energy storage in hydrogen form that uses energy from wind turbine or PV to produce hydrogen for later use is being studied at the hydrogen research institute [4,5]. The idea of an ultra-high-efficiency (UHE) hybrid energy system consisting of wind turbine, a photovoltaic and fuel cell exists in [6,7]. In [8] a management system is designed for a Wind-PV-Fuel cell hybrid energy system to manage the power flow between the system components in order to satisfy the load requirements. In [9] a simple and economic control with DC-DC converter is used for maximum power point tracking and hence maximum power extraction from the wind turbine and photovoltaic arrays. In order to insure continuous power flow a fuel cell was also proposed in this paper. An economic evaluation of a hybrid WindPV-Fuel cell generation system for a house usage is presented in [10]. It is necessary to analyze this system in all aspects such as: cost, efficiency, reliability, dynamic response to load demand and power sources sudden 
changes and its control system. Since, these kinds of hybrid systems are operated under variable conditions such as sudden variations in load demand or wind speed. Therefore in this paper the dynamic response of a WindPV-Fuel cell hybrid energy system is analyzed under some critical operating conditions. It is assumed that the output power of PV plus wind turbine can supply the nominal load demand, in the case of low wind or lack of ambient irradiation a share of power can be supplied from the fuel cell. If PV and wind turbine output power exceeds the demand, the excess power is used to produce hydrogen for later use in the fuel cell. The system description, modeling and a study of system dynamics are presented below.

\section{System Description}

The proposed system consists of a PV array [11], a southwest wind power AIR 404 wind turbine, a proton exchange membrane fuel cell (PEMFC), an ultracapacitor bank, an electrolyzer, power converter and inverter, a wind mast, a dump load, and controllers like in [6]. Schematic diagram of the system is depicted in Figure 1. Wind turbine with an $\mathrm{AC} / \mathrm{DC}$ converter, $\mathrm{PV}$ array and fuel cell with $\mathrm{DC} / \mathrm{DC}$ converters will connect together to a dc bus and after that an inverter will convert this DC power to AC one to supply the load. The load electricity demand is supplied from wind turbine output power plus PV array output in normal operation condition of the system. Each of these two power sources has its own controller. A storage tank with an initial amount of hydrogen is also taken into account to see fuel storage variations. The fuel cell stack is consists of 65 individual fuel cells connected in series. Fuel cell controllers are designed to control $\mathrm{O}_{2}$ and $\mathrm{H}_{2}$ flows in order to produce more power. These controllers will let more fuel flow as fuel cell voltage drops under 60 volts. This action will prevent voltage variations caused by load current changes.
The ultra capacitor bank is in parallel with fuel cell output to reduce sudden voltage variation changes. This system is also consists a power conditioner block which is composed of a boost converter that regulates the DC bus voltage in 200 volts and an inverter that converts this DC power into usable AC power for the system load. The system is modeled by standard classical method $[12,13]$. A set of differential equations and PID controllers by a transfer function is used for modeling.

\subsection{Overall Power Management Strategy}

Figure 2 shows the block diagram of the overall control strategy for the proposed hybrid energy system. Strategy of system operation is according to the following rules:

1) If load demand $\left(\mathrm{P}_{\text {Load }}\right)$ exceeds the available power generated by wind $\left(\mathrm{P}_{\text {wind }}\right)$ and solar sources $\left(\mathrm{P}_{\mathrm{PV}}\right)$ the fuel cell $\left(\mathrm{P}_{\mathrm{FC}}\right)$ will come into action. Therefore, the power balance equation can be written as:

$$
\mathrm{P}_{\text {Load }}=\mathrm{P}_{\text {wind }}+\mathrm{P}_{\mathrm{PV}}+\mathrm{P}_{\mathrm{FC}}, \mathrm{P}_{\text {sys }}<0
$$

2) If the wind and solar generations exceeds the load demand, then the surplus power is diverted toward the electrolyzer. Therefore, the power balance equation can be written as:

$$
\mathrm{P}_{\text {elec }}=\mathrm{P}_{\text {wind }}+\mathrm{P}_{\mathrm{PV}}-\mathrm{P}_{\text {Load }}, \mathrm{P}_{\text {sys }}>0
$$

3 ) If the wind and solar generations equal the load demand, then whole power generated by renewable sources is injected to the load. Therefore, the power balance equation can be written as:

$$
\mathrm{P}_{\text {Load }}=\mathrm{P}_{\text {wind }}+\mathrm{P}_{\mathrm{PV}}, \mathrm{P}_{\text {sys }}=0
$$

\section{Wind-PV-Fuel Cell System Modeling}

As it can be seen in Figure 1, the system consists of bine, PV arrays, fuel cell stack, hydrogen storage tank, elec-

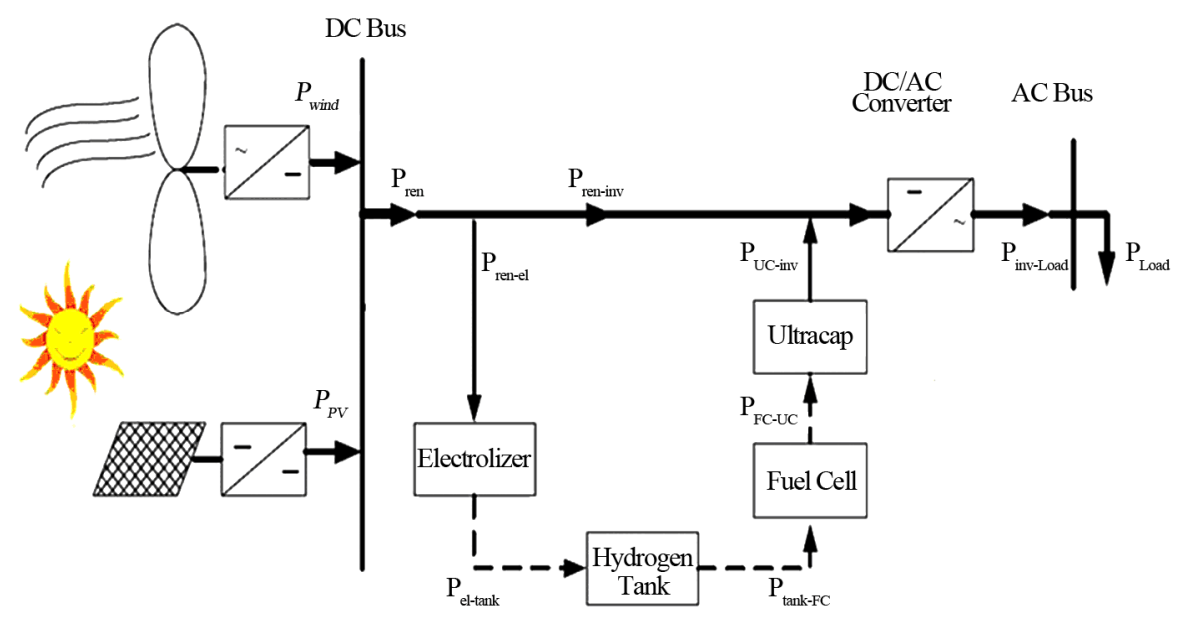

Figure 1. Configuration of hybrid energy system. 


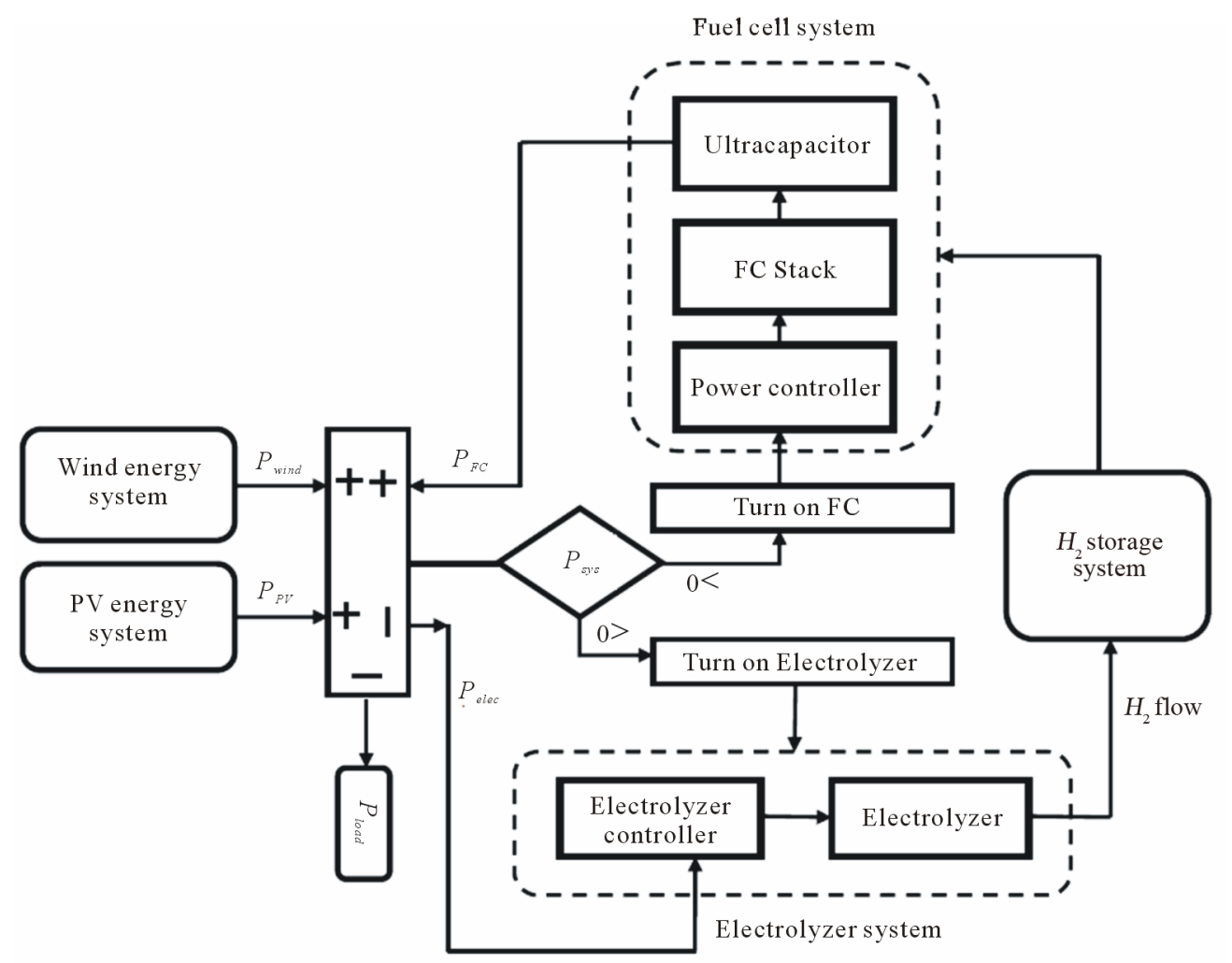

Figure 2. Block diagram of the overall control scheme for the proposed hybrid energy system.

trolyzer, ultracapacitors, power converter and controllers. Dynamic component models, used in this study, are summarized in the following sections $[12,13]$.

\subsection{Photovoltaic Model}

PV effect is a basic physical process through which solar energy is converted directly into electrical energy. The PV cell, or a solar cell, is presented by an electrical equivalent one-diode model $[11,14]$ as shown in Figure 3. The model contains a current source $\mathrm{I}_{\mathrm{L}}$, one diode and a series resistance $R_{s}$ (in ohms), which represents the resistance inside each cell and in the connection between the cells. Relationship between the output voltage V (in volts), and the load current I (in amperes) of a PV cell or a module can be expressed as [11]

$$
I=I_{L}-I_{D}=I_{L}-I_{0}\left(\exp \frac{e \cdot\left(V+I_{s}\right)}{m \cdot k \cdot T_{c}}-1\right)
$$

where $\mathrm{I}_{0}$ is the saturation current, $\mathrm{m}$ is idealizing factor, $\mathrm{k}$ is Boltzmann's gas constant, $\mathrm{T}_{\mathrm{c}}$ is the absolute temperature of the cell and e is electronic charge [11]. The I - V characteristic curves of the PV model for a certain ambient irradiation and cell temperature are given in Figure 4. Effect of cell temperature variation in open circuit voltage is also considered in this model. In Figure 4, $\mathrm{I}_{\mathrm{sc}}$ is the short circuit current, $\mathrm{V}_{\mathrm{oc}}$ is the open circuit voltage, $\mathrm{A}$ $\left(\mathrm{V}_{\max } \mathrm{I}_{\max }\right)$ is the maximum power point on the curve where the load resistance is $\mathrm{R}_{\mathrm{opt}}, \mathrm{MN}$ and PS are constant current and constant voltage criteria respectively. The manufacturers supply PV cells in modules consisting of $\mathrm{N}_{\mathrm{PM}}$ parallel branches and $\mathrm{N}_{\mathrm{SM}}$ solar cells in series. We take $\mathrm{N}_{\mathrm{PM}}$ and $\mathrm{N}_{\mathrm{SM}}$ equal to 10,000 and 2000 respectively.

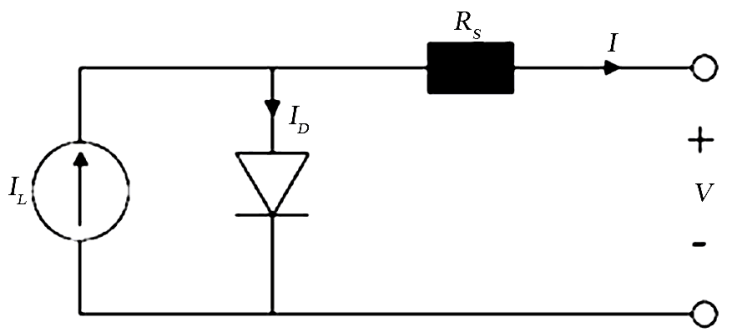

Figure 3. Model for a single solar cell.

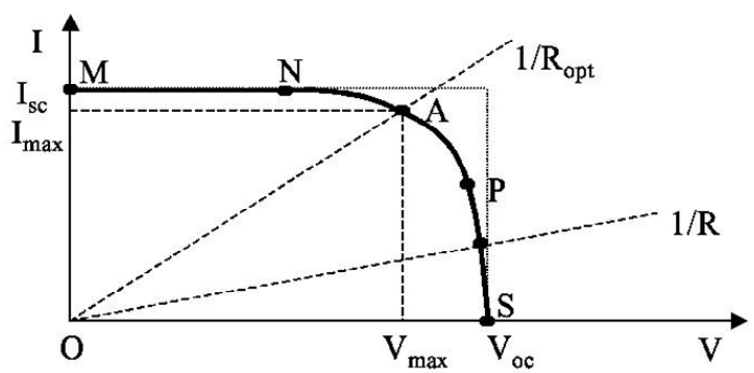

Figure 4. Current-voltage curve for a PV cell. 


\subsection{Wind Turbine Model}

This variable speed wind turbine is self-regulating with a permanent magnet alternator. Self regulation is achieved by twisting of blades (stall control). If the wind speed increases to more than a specific number the wind turbine quickly enters stall mode. It can avoid over speeds by twisting its blades. This small wind turbine has the ability of adapting itself to the wind speeds up to 17.9 $\mathrm{m} / \mathrm{s}$ to achieve maximum available power. Turbine rotor diameter is $1.14 \mathrm{~m}$. The wind turbine power curve is as the way illustrated in Figure 5 [12,15]. The dynamic of wind turbine due to its rotor inertia $(\mathrm{J})$, and controller action is as Equation (5) when a friction based dynamic model for the wind turbine rotor and a first order model for the permanent magnet generator are used [12].

$$
\frac{y(\mathrm{~s})}{x(\mathrm{~s})}=\frac{0.25}{\mathrm{~s}^{2}+0.7 \mathrm{~s}+0.25}
$$

where $x(t)$ is the power from the curve shown in Figure 5 and $y(\mathrm{t})$ is the actual wind turbine output power.

\subsection{Fuel Cell Model}

Fuel cells are electrochemical devices that convert the chemical energy of a reaction directly into electrical energy. Exchange membrane fuel-cell (PEMFC) has reliable performance under intermittent supply and is commercially available at large industrial scale capacities. This kind of fuel cell is suitable for large-scale stationary generation and has fast dynamic response with a power release response time of only $1-3 \mathrm{~s}$ [16]. In this paper a group of PEMFC stacks were applied to enhance the performance of the hybrid system. Parametric model of PEMFC developed by Amphlett $[17,18]$ using mechanistic approach and a number of group parameters is used. The number of stacks is 65 . The $\mathrm{H}_{2}$ and $\mathrm{O}_{2}$ pressure, current drawn and temperature variations can affect the fuel cell output voltage. These voltage variations can be compensated by fuel pressure controlling. Figure 5 is shown the electrical equivalent of fuel cell. $\mathrm{E}$ is thermodynamic potential, $R_{a}$ is the activation resistance and $R_{i n t}$ is the fuel cell internal resistant. The dynamics of the fuel cell voltage can be modeled by the addition of a capacitor $\mathrm{C}$ to the steady state model [19]. The effect of double charge layer is also modeled by a capacitor $\mathrm{C}$ connected in parallel with the activation resistance as shown in Figure 6.

Fuel cell has two PID controller loops; one for $\mathrm{O}_{2}$ and the other for $\mathrm{H}_{2}$ pressure. The controller gains are presented in Table 1. The controllers will become activated when the output voltage of Fuel cell drops below $60 \mathrm{~V}$.

\subsection{Electrolyzer Model}

The Electrolyzer works through simple water electrolysis: a direct current is passed between two electrodes submerged in water, which thereby decomposes into hydrogen and oxygen. The hydrogen can then be collected from the anode. The production rate of hydrogen in an electrolyzer cell according to Faraday law can be achieved through Equation (6).

$$
\mathrm{n}_{\mathrm{H}_{2}}=\frac{\eta_{\mathrm{F}} \mathrm{n}_{\mathrm{c}} \mathrm{i}_{\mathrm{e}}}{2}(\mathrm{~mol} / \mathrm{s})
$$

where $i_{e}$ is the electrolyzer current, $n_{c}$ is the number of electrolyzer cells in series and $\eta_{\mathrm{F}}$ is the Faraday efficiency. For an electrolyzer working in $40^{\circ} \mathrm{C}$; Faraday efficiency can be calculated as:

$$
\eta_{\mathrm{F}}=96.5 \exp \left(0.09 / \mathrm{i}_{\mathrm{e}}-75.5 / \mathrm{i}_{\mathrm{e}}^{2}\right)
$$

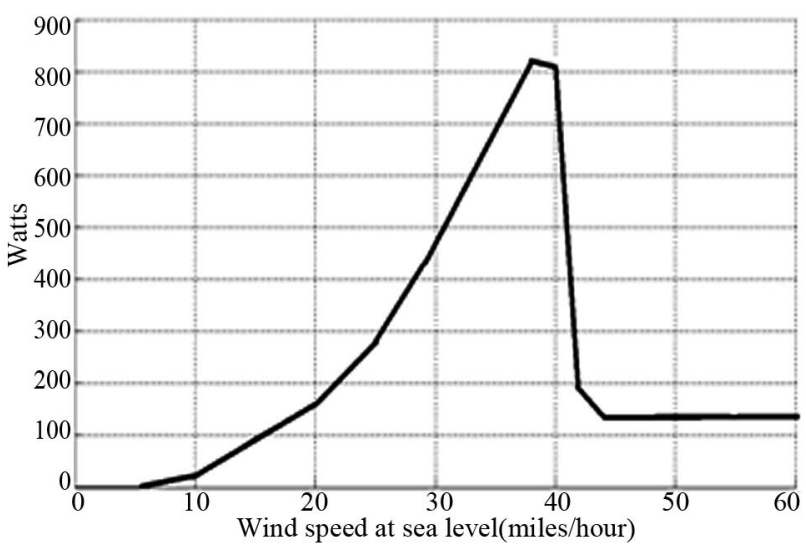

Figure 5. Power curve of wind turbine.

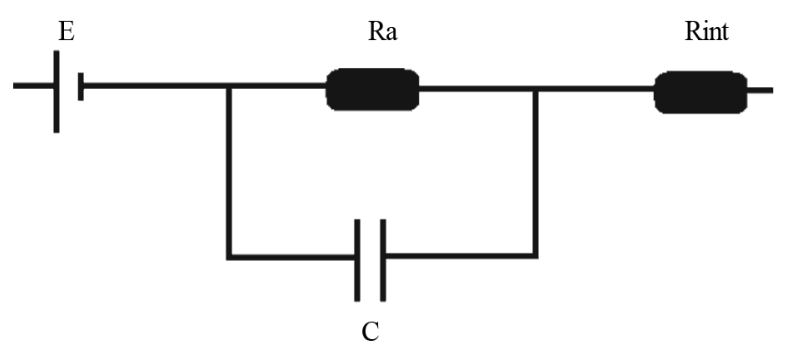

Figure 6. Equivalent circuit of PEMFC.

Table 1. PID Controllers parameters.

\begin{tabular}{cccc}
\hline & $\mathrm{K}_{\mathrm{p}}$ & $\mathrm{T}_{\mathrm{i}}$ & $\mathrm{T}_{\mathrm{d}}$ \\
\hline Fuel-cell $\mathrm{O}_{2}$ flow controller & 3.14 & 0.5 & 0 \\
Fuel-cell $\mathrm{H}_{2}$ flow controller & 5 & 0.5 & 0 \\
Boost converter & 5 & 0.5 & 0 \\
Inverter & 0.03 & 0.15 & 0 \\
\hline
\end{tabular}


In this paper we assume that the electrolyzer temperature to be constant. Dynamic modeling of electrolyzer and fuel cells auxiliary equipment such as hydrogen storage vessel, compressor, piping, valves, etc., are neglected.

\subsection{Ultracapacitor Model}

Ultracapacitors are energy storage devices with a construction similar to batteries [13]. It can store energy and release it when it is necessary. This can help the system in short duration of the peak power. Such a device can be use in parallel with fuel cell to reduce its voltage variations due to power variations. Ultracapacitors are with low voltage rates. We have used four modules of Maxwell $435 \mathrm{~F}, 14 \mathrm{~V}$ ultracapacitor like in [13] to achieve the desired operating voltage. The ultracapacitor can be modeled using a capacitor in series with a resistor. Four ultracapacitors modules in series have a total capacitance (C) of $108.75 \mu \mathrm{F}$. each module has a series resistance $\left(\mathrm{R}_{\mathrm{c}}\right)$ of $4 \mathrm{~m} \Omega$. Ultracapacitor is modeled as a low pass filter with the transfer function in Equation (8).

$$
\frac{\mathrm{V}_{\text {ucap }}}{\mathrm{V}_{\text {Fcell }}}=\frac{\mathrm{s}+1 / \mathrm{R}_{\mathrm{c}} \mathrm{C}}{\mathrm{s}\left(1+\mathrm{R}_{\mathrm{s}} / \mathrm{R}_{\mathrm{c}}\right)+1 / \mathrm{R}_{\mathrm{c}} \mathrm{C}}
$$

where $R_{s}$ is the stray capacitance and is equal to $0.01 \Omega$.

\subsection{Power Conditioner}

The system is considered for stand-alone mode of operation and a two-stage power converter module is considered to regulate the output voltage at a standard magni tude and frequency. The first stage consists of a boost converter, which can regulate the output voltage into a high voltage constant DC that is appropriate for the load usage. Here, the boost converter is controlled with a PID controller to regulate the high voltage bus at $200 \mathrm{~V}$. This could be achieved by adjusting the duty ratio, D, as generally given by the Equation (9).

$$
\frac{\mathrm{V}_{\text {boost }}}{\mathrm{V}_{\text {ucap }}}=\frac{1}{1-\mathrm{D}}
$$

To supply the load the ac power can be achieved through an inverter connected to the output of the boosting converter. A pulse width modulation (PWM) singlephase voltage source converter is used to control the output voltage of the system. A PID controller is used to control the voltage on $120 \mathrm{~V}$ and $60 \mathrm{HZ}$. The triangular carrier wave frequency is considered to be $8 \mathrm{kHz}$ [13].

\subsection{Controllers}

All subsystems controllers are chosen PID type in this system, which have transfer function like in Equation (10). Appropriate controller parameters are available in Table 1.

$$
T(s)=\frac{K_{p}\left(s+T_{d} s^{2}+1 / T\right)}{s}
$$

\section{Simulation and Discussion}

The simulated system in Matlab SIMULINK [20] is presented in Figure 7 [20]. It consists of seven main

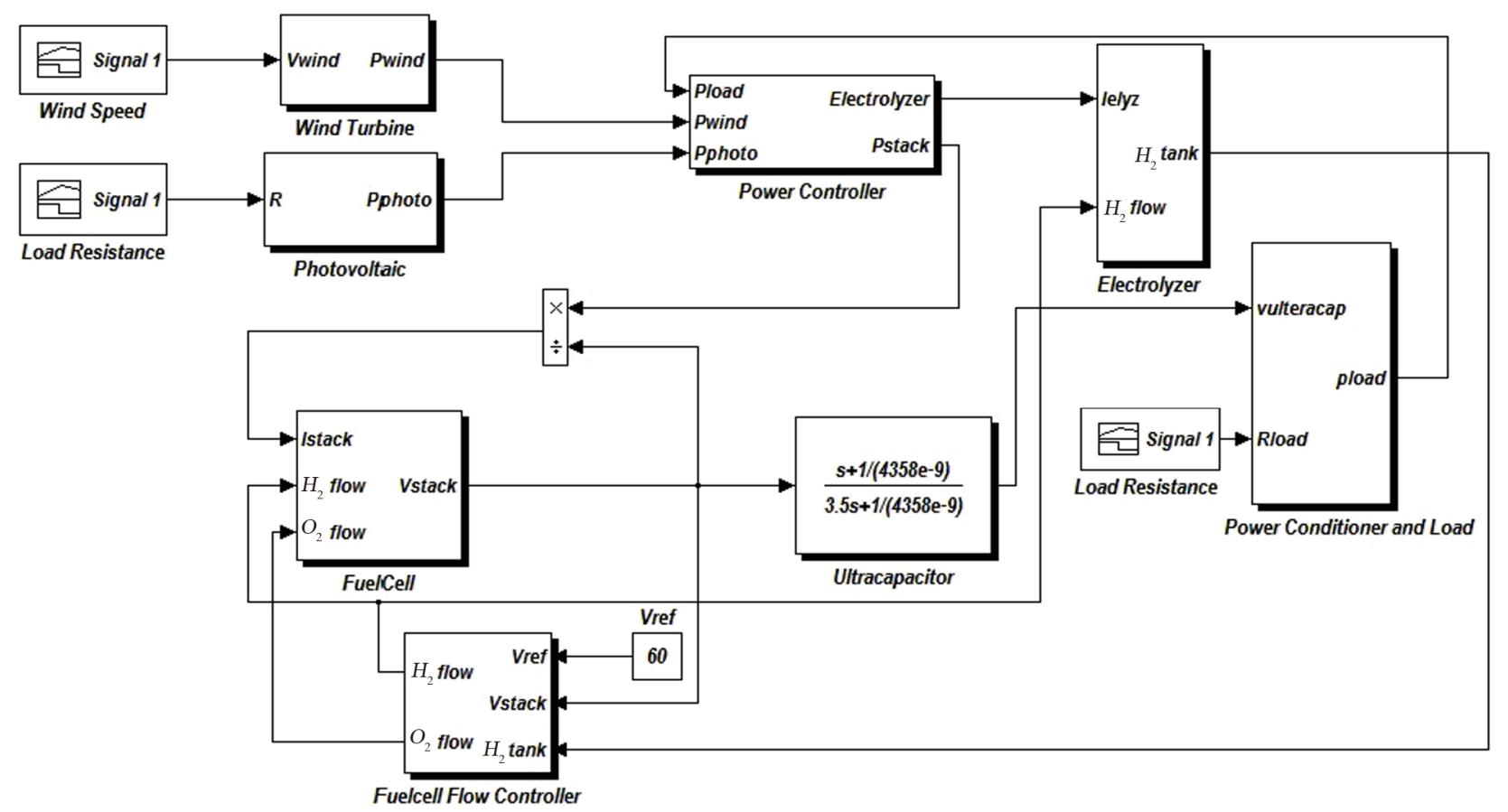

Figure 7. Simulated system in Matlab SIMULINK. 
subsystems that have been described in previous sections. Wind turbine input and load resistance are two variable inputs of the system. A fixed inductive load $(100 \mathrm{mH})$ is also added to variable resistive load. Step changes in load resistance and wind speed are applied to analyze the dynamic response of the system. Load resistance changes at $\mathrm{t}=10 \mathrm{~s}$ from $35 \Omega$ to $10 \Omega$ and $\mathrm{t}=20 \mathrm{~s}$ from $10 \Omega$ to 25 $\Omega$ as seen in Figure 8. Wind speed changes at $t=20 \mathrm{~s}$ from 9 to $12 \mathrm{~m} / \mathrm{s}$ and returns to $9 \mathrm{~m} / \mathrm{s}$ at $\mathrm{t}=30 \mathrm{~s}$ as it is clear from Figure 9. Simulation is run for 40 seconds. Results are presented in Figures 10-18. Effects of input step changes are obvious in the results. Figure 10 shows the demand power, wind turbine, photovoltaic and fuel cell output powers. As it is clear the demand power increases at $\mathrm{t}=10 \mathrm{~s}$ and decreases in $\mathrm{t}=20 \mathrm{~s}$ by changes in load resistance.

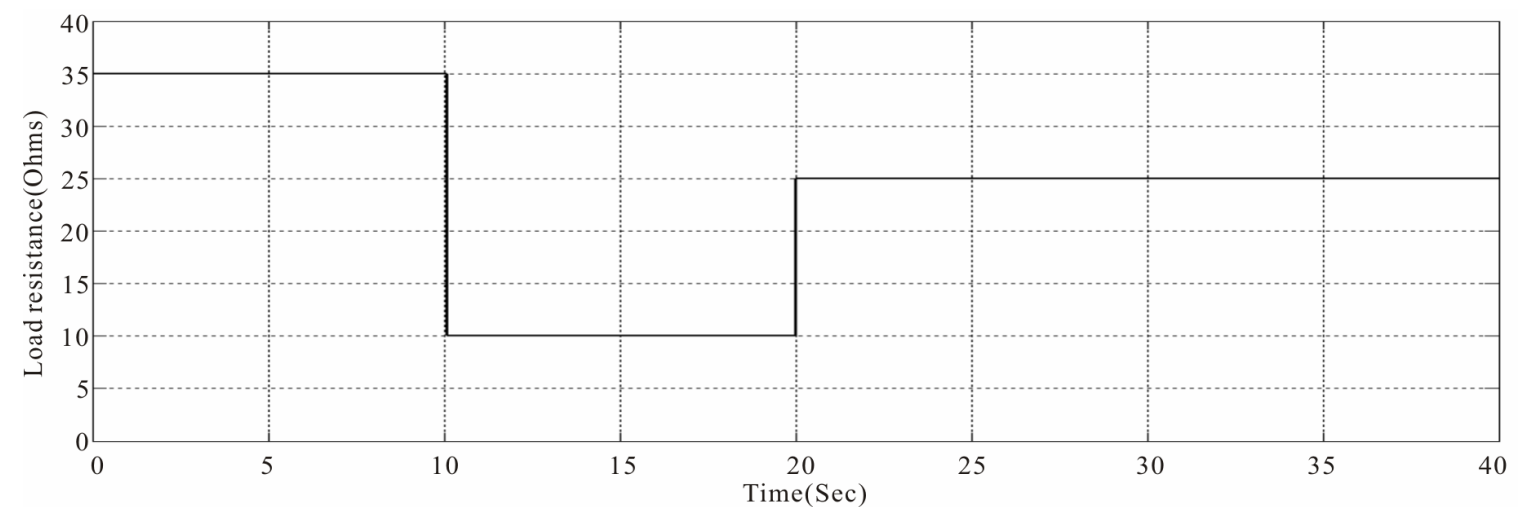

Figure 8. Load resistance.

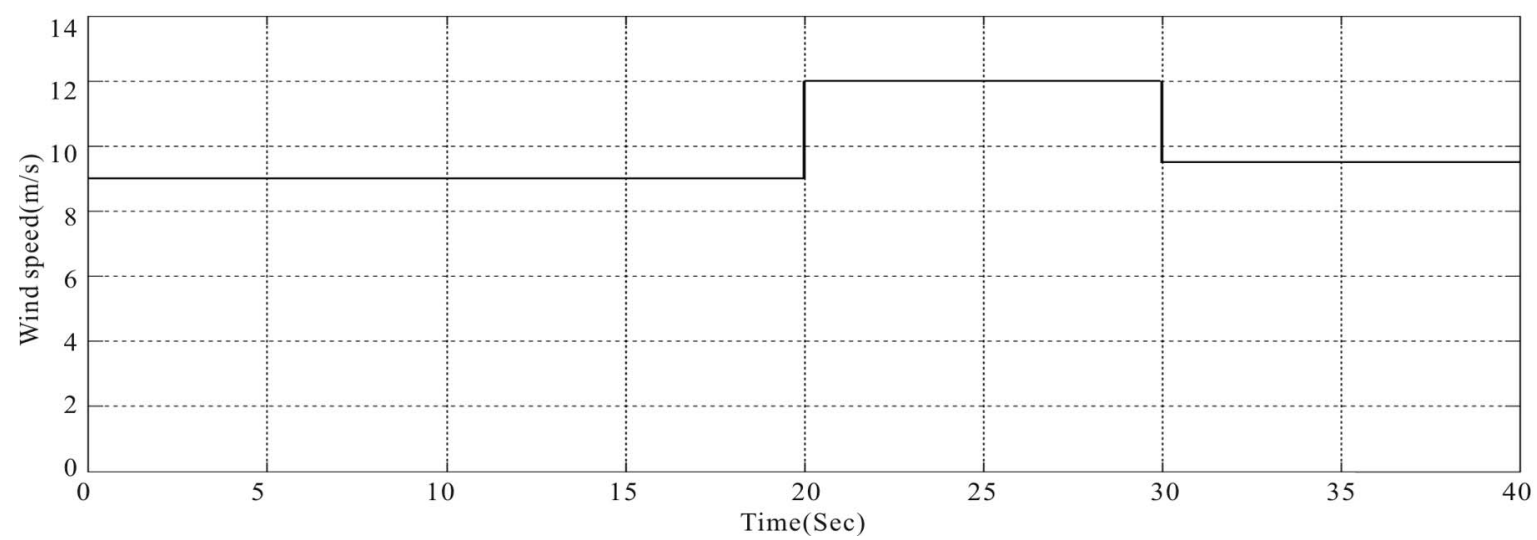

Figure 9. Wind turbine input.

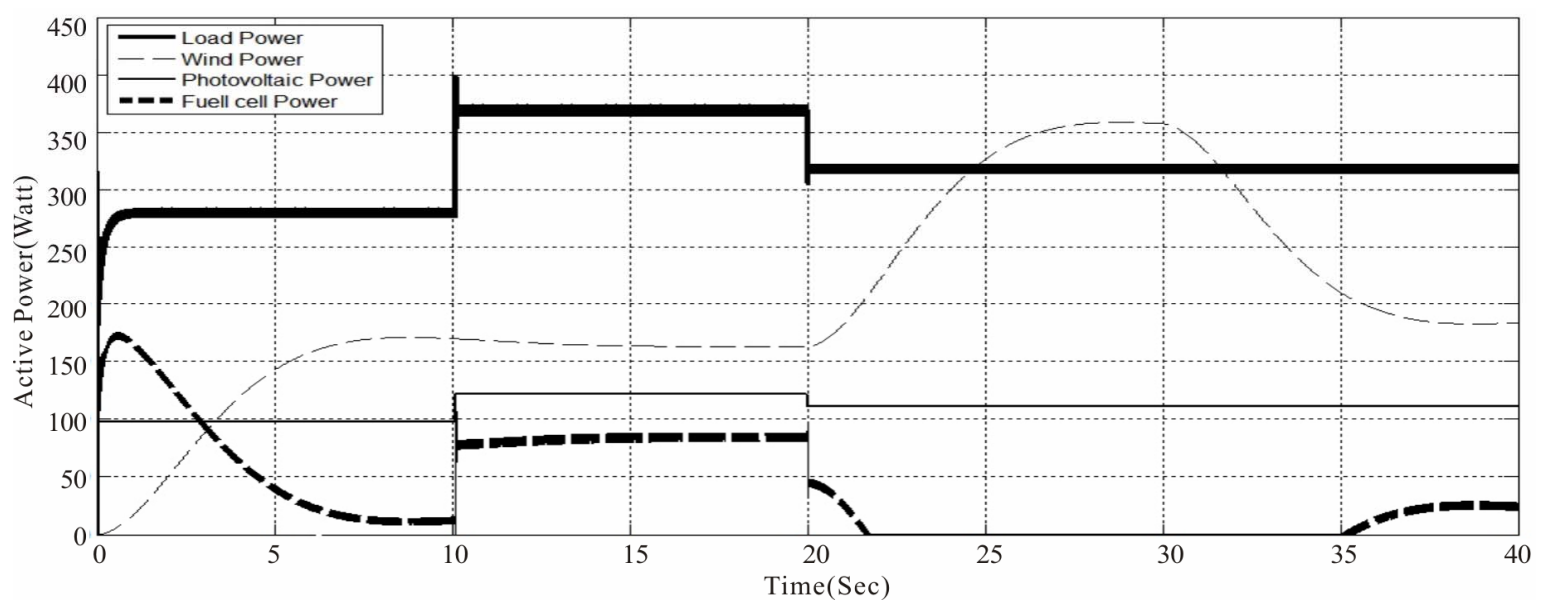

Figure 10. Load, fuel cell, PV and wind powers. 
The lack of power in $\mathrm{t}=10 \mathrm{~s}$ is compensated by an increase in $\mathrm{O}_{2}$ and $\mathrm{H}_{2}$ pressure and as a result a step change in output power of fuel cell. Gas pressure variations in fuel cell are presented in Figure 11. Resistance change effects on output power of photovoltaic are also obvious in Figure 10. Both PV and fuel cell output powers are decreases when load resistance is increased at $\mathrm{t}=20 \mathrm{~s}$. Output power of wind generator at $\mathrm{t}=20 \mathrm{~s}$ is increased after variations in wind speed. As it is obvious generated power by PV and wind turbine is excess the load demand at $\mathrm{t}=22 \mathrm{~s}$. The excess generated power is converted into hydrogen to save in a tank for later use. The hydrogengenerated $(\mathrm{mol} / \mathrm{s})$ in electrolyzer is presented in Figure 12. Although there is step variations in load and wind turbine output power but as it is clear in Figure 13, the inverter and boosting converter could regulate voltage

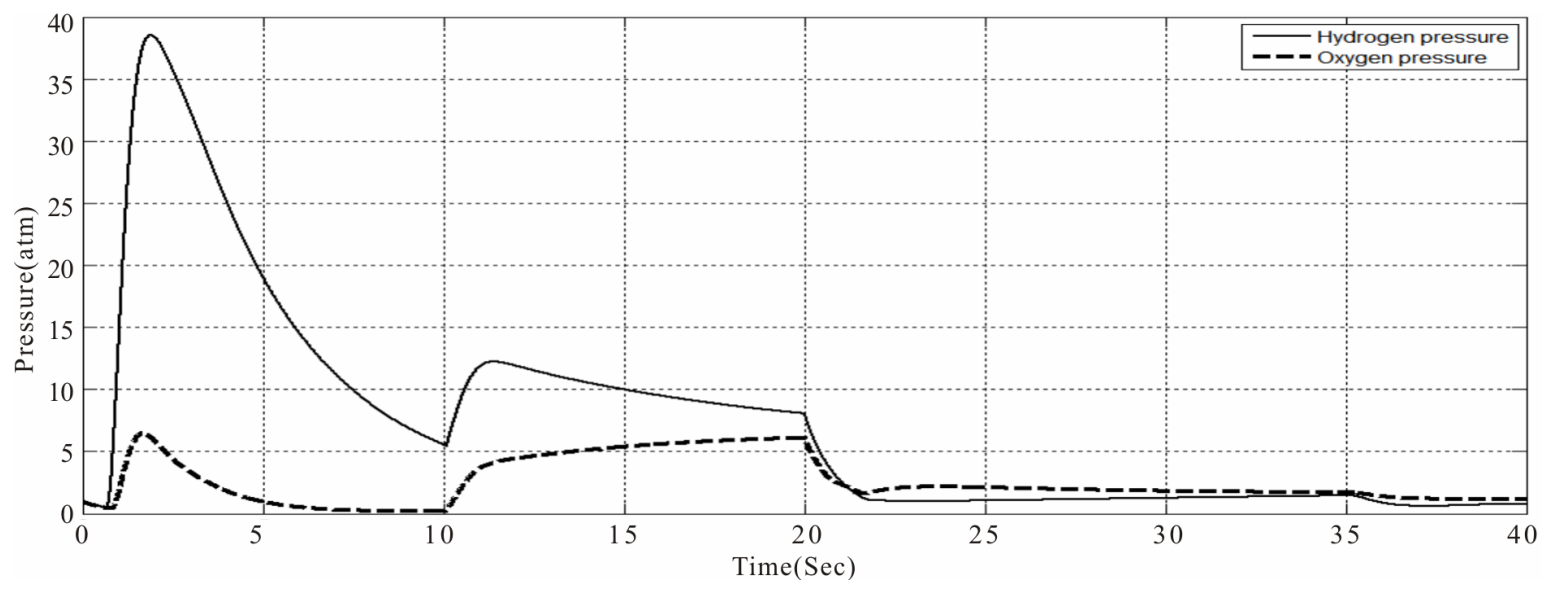

Figure 11. Fuel-cell's gas pressure.

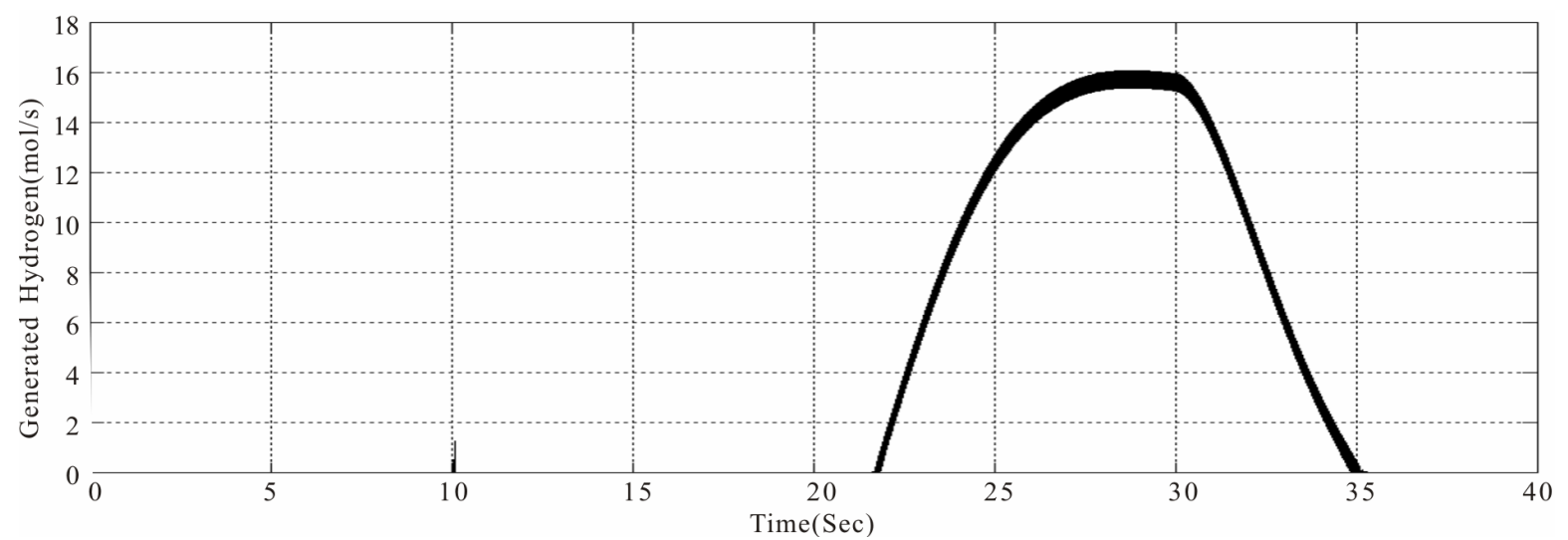

Figure 12. Generated $\mathrm{H}_{2}$ by electrolyzer.

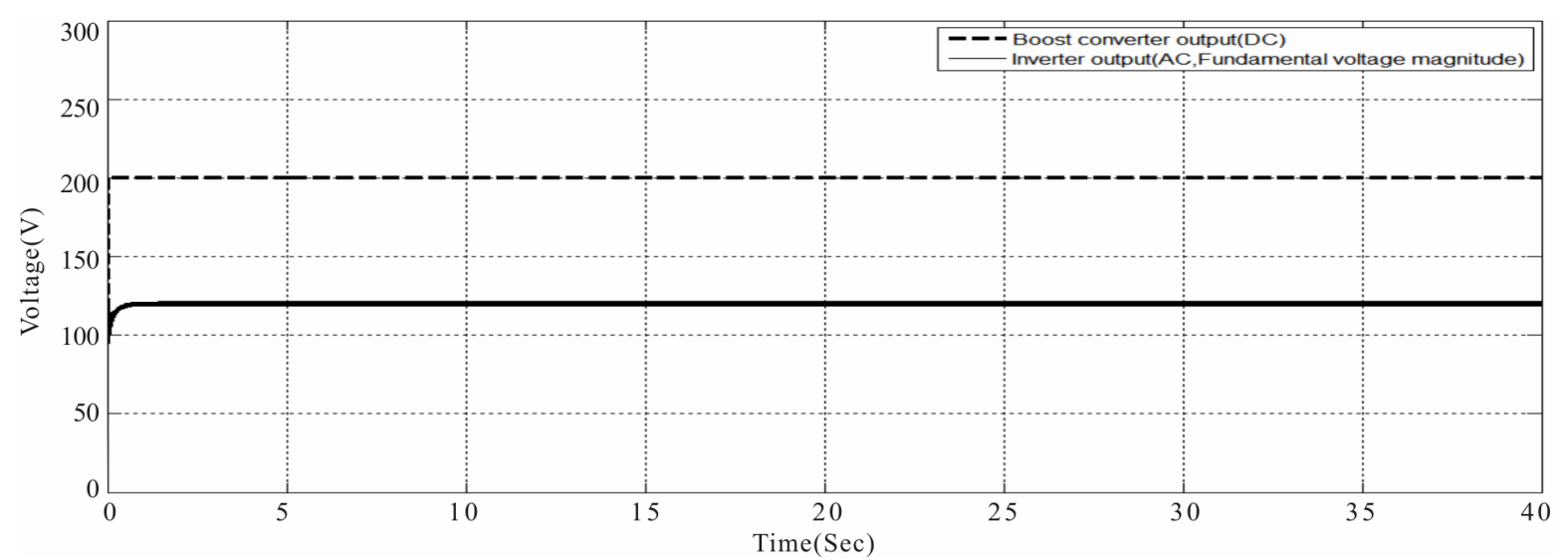

Figure 13. Inverter and converter output voltages. 
properly. Photovoltaic current and voltage are shown in Figures 14 and 15. Load current and voltage, ultracapacitor voltage are illustrated in Figures 16-18 respectively. The contribution of fuel cell is decreased by using
PV arrays and wind turbine simultaneously in parallel with fuel cell. In $\mathrm{t}=22$ to $35 \mathrm{~s}$ fuel cell is not working, this can help in long-term use to increase life-time of this expensive device. So a system consists of PV, wind

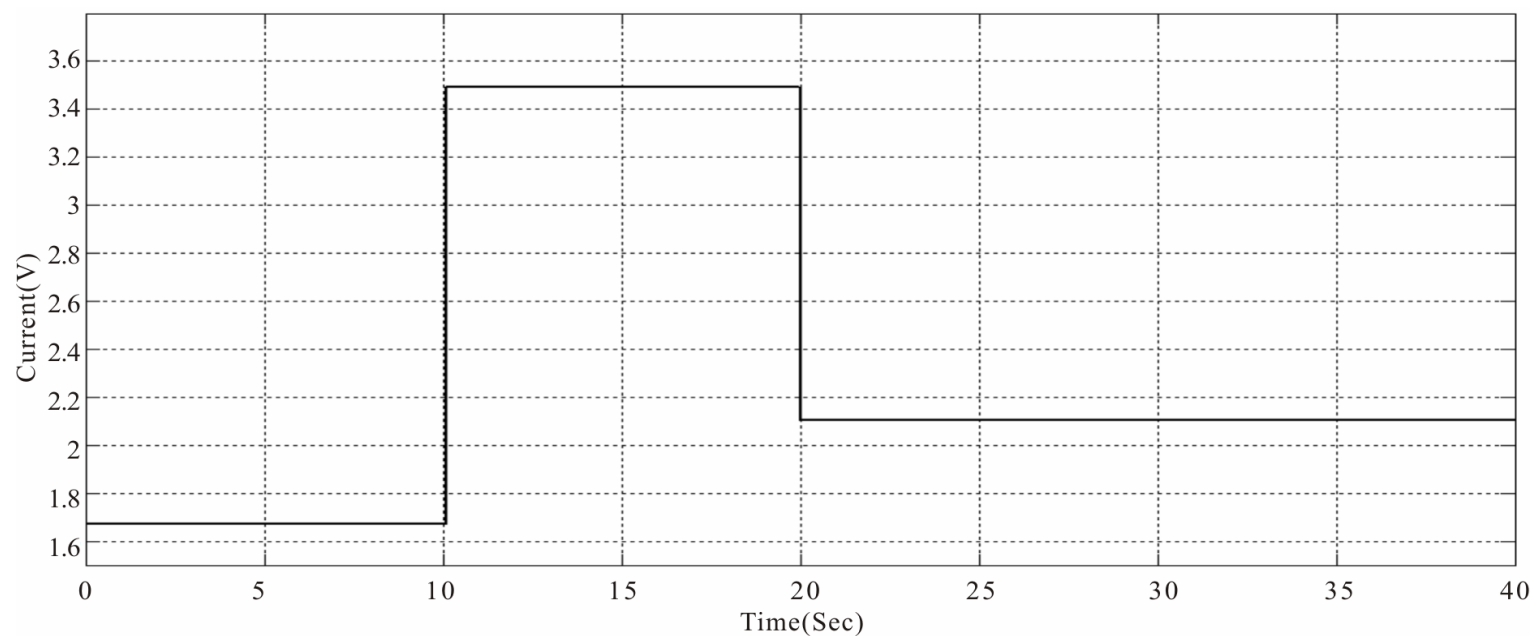

Figure 14. PV current waveform.

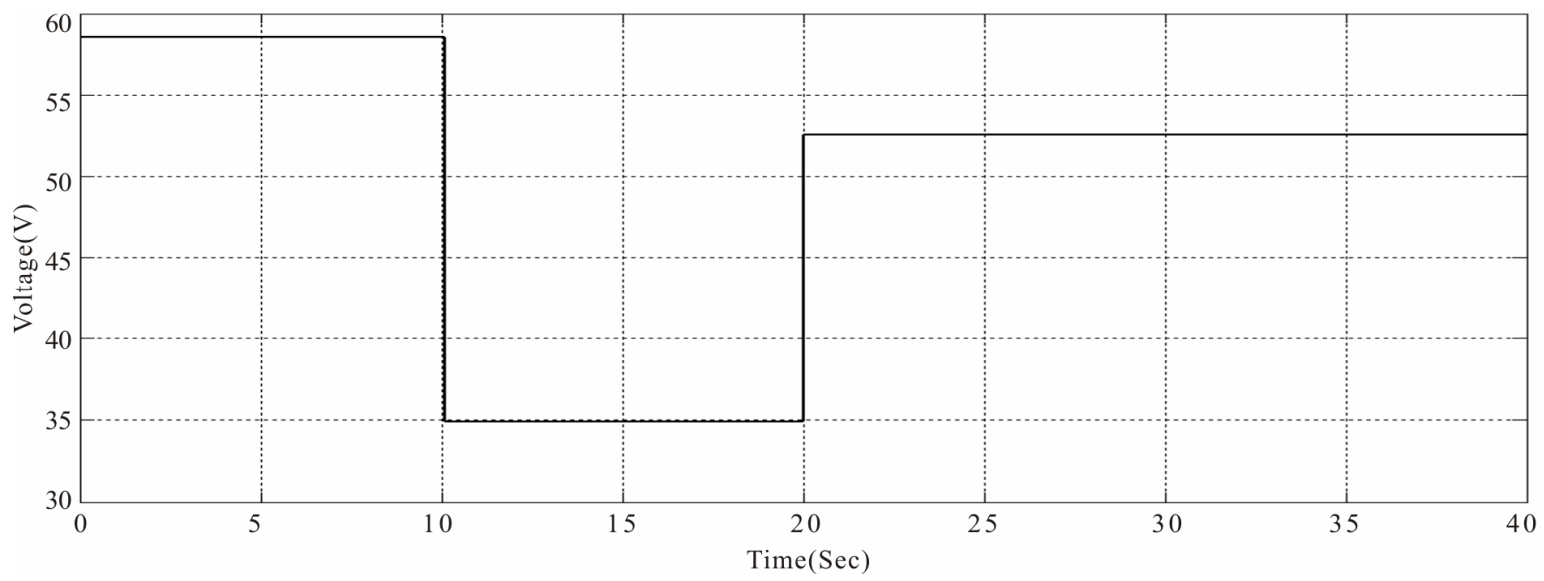

Figure 15. PV voltage waveform.

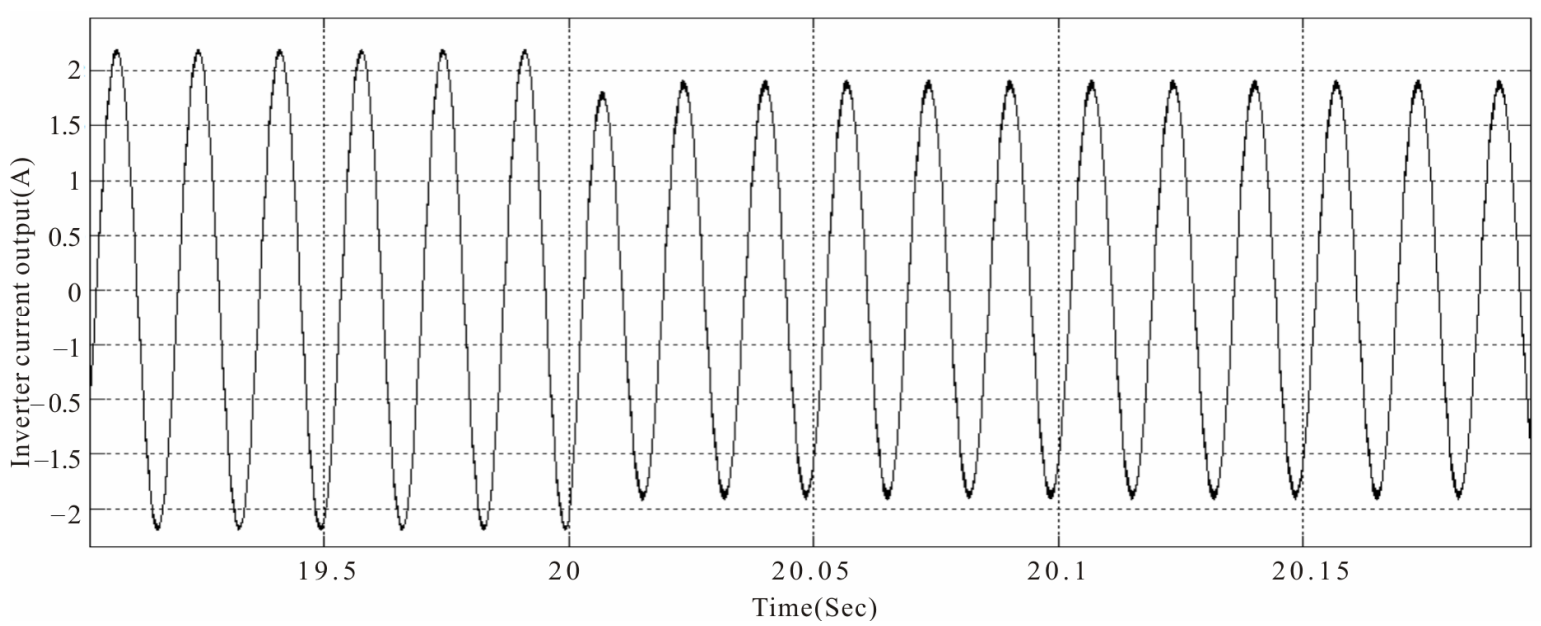

Figure 16. Load current zoomed in $t=20 \mathrm{~s}$. 


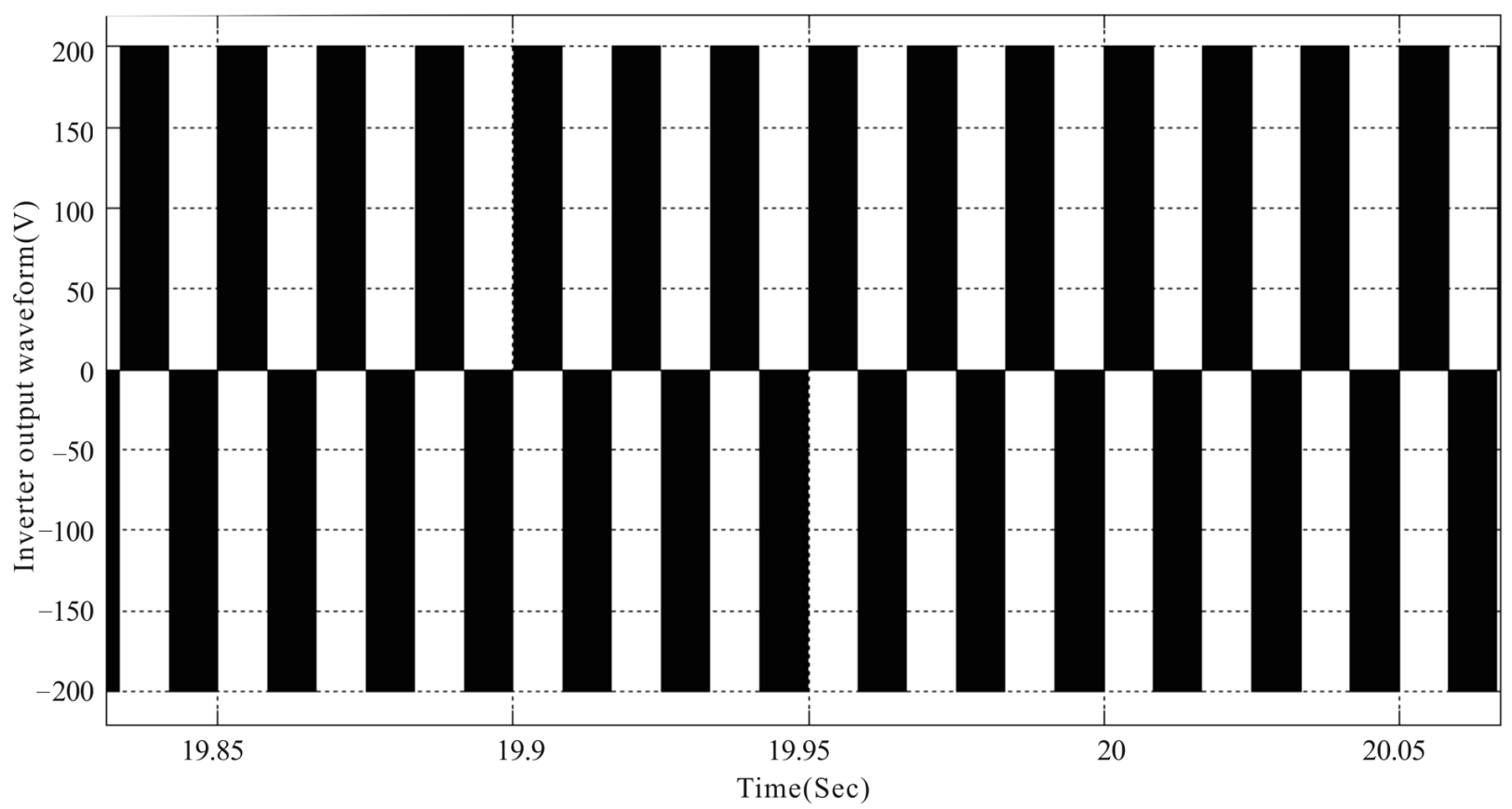

Figure 17. Load voltage waveform.

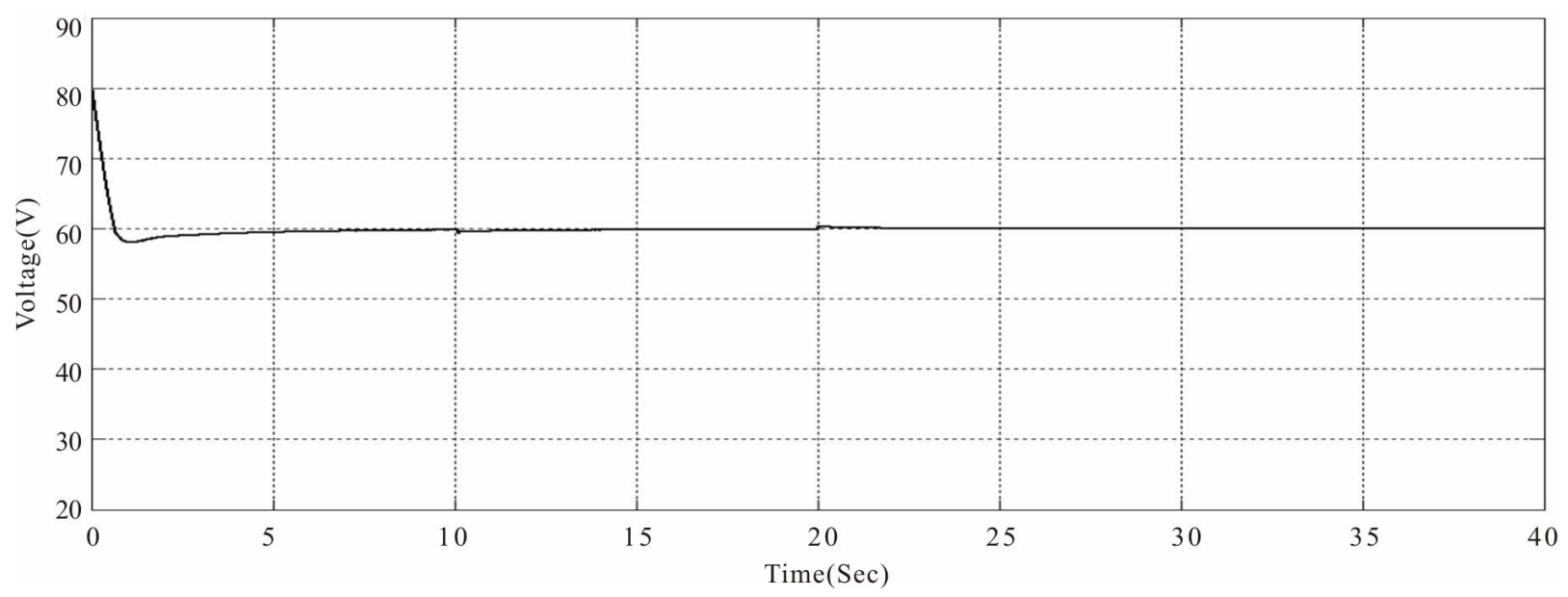

Figure 18. Ultracapacitor voltage waveform.

turbine and fuel cell is preferable from economical aspect. The other advantage of this system is its reliability because of three different devices in parallel. Each of these devices shows different characteristic in different can compensate the weakness of other devices.

\section{Conclusion}

A small $500 \mathrm{~W}$ wind-photovoltaic-fuel cell hybrid energy system for stand-alone operation is proposed in this paper. The design and analysis of this demonstration type ultra-low emission energy system are presented. System dynamic modeling, simulation, and design of controller are reported in this work. All system models were described through mathematical aspect. Results show that the effectiveness of this hybrid energy system. Such a system shows its ability to supply a variable load without interruption. The system is more reliable in comparison to a wind-fuel cell hybrid system, because of three systems in parallel and their different characteristics. It is more economical to supply the load by this hybrid energy system because it doesn't need the fuel cell to work all day long. The system performance can satisfy the user in all perspectives. It could regulate the output power properly while its transients were damped very quickly.

\section{Acknowledgements}

The support of the International Center for Science, High Technology \& Environmental Sciences, Kerman, Iran 
under grant No. 1/670 is gratefully acknowledged.

\section{REFERENCES}

[1] B. S. Borowy and Z. M. Salameh, "Optimum Photovoltaic Array Size for a Hybrid Wind/PV System," IEEE Transactions on Energy Conversion, Vol. 9, No. 3, 1994, pp. 482-488. doi:10.1109/60.326466

[2] B. S. Borowy and Z. M. Salameh, "Methodology for Optimally Sizing the Combination of a Battery Bank and PV Array in a Wind/PV Hybrid System," IEEE Transactions on Energy Conversion, Vol. 11, No. 2, 1996, pp. 367-374. doi:10.1109/60.507648

[3] A. N. Celik, "Optimisation and Techno-Economic Analysis of Autonomous Photovoltaic-Wind hybrid Energy Systems in Comparison to Single Photovoltaic and Wind Systems," Energy Conversion and Management, Vol. 43, No. 18, 2002, pp. 2453-2468. doi:10.1016/S0196-8904(01)00198-4

[4] K. Agbossuo, R. Chahine, J. Hamelin, F. Laurencelle and J. Hamelin, "Renewable Energy Systems Based on Hydrogen for Remote Applications," Journal of Power Sources, Vol. 96, No. 1, 2001, pp. 168-172. doi:10.1016/S0378-7753(01)00495-5

[5] K. Agbossuo, J. Hamelin, A. Laperriere and F. Laurencelle, "Load Communication for Stand Alone Wind and PV Hydrogen Energy System," Proceedings of Canadian Conference of Electrical and Computer Engineering, Vol. 1, 2000, pp. 555-558.

[6] A. Sathyan, K. A. Kiszynski and S. Al-Hallaj, "Hybrid Wind/PV/Fuel Cell Generation System," IEEE Conference on Vehicle Power and Propulsion, Chicago, 7-9 September 2005, pp. 495-500.

[7] F. Iannone, S. Leva and D. Zaninelli, "Hybrid Photovoltaic and Hybrid Photovoltaic-Fuel Cell System: Economic and Environmental Analysis," IEEE Power Engineering Society General Meeting, San Francisco, 12-16 June 2005, pp. 1503-1509.

[8] T. F. El-Shatter, M. N. Eskander and M. El-Hagry, "Energy Flow and Management of a Hybrid Wind/PV/Fuel Cell Generation System," Energy Conversion and Management, Vol. 47, No. 9-10, 2006, pp. 1264-1280. doi:10.1016/i.enconman.2005.06.022
[9] D. Das, R. Esmaili, L. Xu and D. Nichols, "An Optimal Design of a Grid Connected Hybrid Wind/Photovoltaic/Fuel Cell System for Distributed Energy Production," 31 st Annual Conference of IEEE Industrial Electronics Society, Raleigh, 6-10 November 2005, pp. 2499-2504.

[10] D. B. Nelson, M. H. Nehrir and C. Wang, "Unit Sizing and Cost Analysis of Stand-Alone Hybrid Wind/PV/Fuel Cell Power Generation Systems," Renewable Energy, Vol. 31, No. 10, 2006, pp. 1641-1656. doi:10.1016/j.renene.2005.08.031

[11] A. D. Hansen, P. Sorensen, L. H. Hansen and H. Binder, "Models for a Stand-Alone PV System," Riso National laboratory, Roskilde, 2000.

[12] M. T. Iqbal, "Simulation of a Small Wind Fuel Cell Hybrid Energy System," Renewable Energy, Vol. 28, No. 4, 2003, pp. 511-522.

[13] M. J. Khan and M. T. Iqbal, "Dynamic Modeling and Simulation of a Small Wind-Fuel Cell Hybrid Energy System," Renewable Energy, Vol. 30, No. 3, 2005, pp. 421-439.

[14] M. R. Patel, "Wind and Solar Power Systems," CRC Press, Boca Raton, 1999.

[15] http://www.windenergy.com

[16] R. S. Garcia and D. Weisser, "A Wind-Diesel System with Hydrogen Storage: Joint Optimization of Design and Dispatch," Renewable Energy, Vol. 31, No. 14, 2006, pp. 2296-2320. doi:10.1016/j.renene.2005.11.003

[17] J. C. Amphlett, R. M. Baumert, R. F. Mann, B. A. Peppley, P. R. Roberge and T. J. Harries, "Performance Modeling of the Ballard Mark IV Solid Polymer Electrolyte Fuel Cell," Journal of the Electrochemical Society, Vol. 142, No. 1, 1995, pp. 9-15. doi:10.1149/1.2043959

[18] R. F. Mann, J. C. Amphlett, M. Hooper, H. M. Jensen, B. A. Peppley and P. R. Roberge, "Development and Application of a Generalised Steady-State Electrochemical Model of a PEM Fuel Cell," Journal of Power Sources, Vol. 86, No. 1-2, 2000, pp. 173-180. doi:10.1016/S0378-7753(99)00484-X

[19] J. Larminie and A. Dicks, "Fuel Cell Systems Explained," 2nd Edition, John Wiley and Sons, New York, 2001.

[20] http://www.mathworks.com 